\title{
Prevalence and intensity of infection by Raillietiella gigliolii Hett, 1924 (Pentastomida) in Amphisbaena alba Linnaeus, 1758 and $A$. vermicularis Wagler, 1824 (Amphisbaenidae) from Northeastern Brazil
}

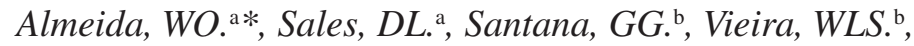 \\ Ribeiro, SC. ${ }^{\mathrm{a}}$, Alves, $R R N .^{\mathrm{c}}$ and Nóbrega, RP. ${ }^{\mathrm{b}}$ \\ aDepartamento de Química Biológica, Centro de Ciências Biológicas e da Saúde - CCBS, \\ Campus do Pimenta, Universidade Regional do Cariri - URCA, \\ CEP 63105-100, Crato, CE, Brazil \\ bPrograma de Pós-Graduação em Ciências Biológicas (Zoologia), Departamento de Sistemática e Ecologia, \\ Laboratório/Coleção de Herpetologia, Centro de Ciências Exatas e da Natureza - CCEN, \\ Universidade Federal da Paraíba - UFBA, \\ Cidade Universitária, Campus I, CEP 58059-900, João Pessoa, PB, Brazil \\ 'Departamento de Biologia - Universidade Estadual da Paraíba, \\ Av. das Baraúnas, 351, Bodocongó, CEP 58109-753, Campina Grande, PB, Brazil \\ *e-mail: waltecio@gmail.com \\ Received August 26, 2008 - Accepted October 20, 2008 - Distributed November 30, 2009
}

\begin{abstract}
Raillietiella gigliolii is a Neotropical pentastomid parasite found in Amphisbaena alba. Collections were made in northeastern Brazil in a remnant area of Atlantic Forest $\left(07^{\circ} 10^{\prime} \mathrm{S}\right.$ and $\left.35^{\circ} 05^{\prime} \mathrm{W}\right)$ in the municipality of Cruz do Espírito Santo, Paraíba State, and in a Humid Forest area $\left(07^{\circ} 16^{\prime} \mathrm{S}\right.$ and $\left.39^{\circ} 26^{\prime} \mathrm{W}\right)$ on the slopes of the Chapada do Araripe Mountains, municipality of Crato, Ceará state, Brazil. Nine specimens of A. alba and 12 of A. vermicularis were collected to gather basic ecological data (prevalence and mean intensity of infection) concerning these parasites. Raillietiella gigliolii was found infecting the lungs of both species. The prevalence for A. alba was 55.5\% (5/9), with a mean intensity of infection of $5.0 \pm 2.53$ and amplitudes of 1-13. A. vermicularis demonstrated prevalence of $50 \%$, with a mean intensity of infection of $5.3 \pm 2.1$ and amplitudes of 1-14. This represents the first record of $R$. gigliolii as a parasite of $A$. vermicularis. Our results suggest that $R$. gigliolii is a generalist parasite species and that an overlapping diet is the determinant factor in the sharing of its final hosts.
\end{abstract}

Keywords: endoparasites, Amphisbaena, Raillietiella, Neotropical region.

\author{
Prevalência e intensidade de infecção por Raillietiella gigliolii Hett, 1924 \\ (Pentastomida) em Amphisbaena alba Linnaeus, 1758 e \\ A. vermicularis Wagler, 1824 (Amphisbaenidae) da região Nordeste do Brasil
}

\begin{abstract}
Resumo
Raillietiella gigliolii constitui uma espécie de pentastomídeo neotropical parasita registrada em Amphisbaena alba. No intuito de suplementar dados ecológicos básicos (prevalência e intensidade média de infecção) foram coletados na região nordeste do Brasil nove espécimes de A. alba em um remanescente de Mata Atlântica $\left(07^{\circ} 10^{\prime} \mathrm{S}\right.$ e $\left.35^{\circ} 05^{\prime} \mathrm{O}\right)$ no município de Cruz do Espírito Santo, Estado da Paraíba, e 12 A. vermicularis em ambiente de Mata Úmida ( $07^{\circ} 16^{\prime} \mathrm{S}$ e $\left.39^{\circ} 26^{\prime} \mathrm{O}\right)$ na encosta da Chapada do Araripe, município de Crato, Estado do Ceará. Em ambas as espécies foi encontrada $R$. gigliolii infectando os pulmões analisados. A prevalência encontrada para A. alba foi de 55,5\% (5/9) com intensidade média de infecção de 5,0 \pm 2,53, amplitude 1-13. Em A. vermicularis, encontramos uma prevalência de $50 \%$ e intensidade média de infecção de 5,3 $\pm 2,1$, amplitude 1-14. Este representa o primeiro registro de $R$. gigliolii como parasita de A. vermicularis. Os resultados sugerem que $R$. gigliolii constitui uma espécie generalista e a superposição da dieta parece ser o fator determinante para o compartilhamento de hospedeiros definitivos.
\end{abstract}

Palavras-chave: endoparasitas, Amphisbaena, Raillietiella, região Neotropical. 


\section{Introduction}

Brazil has approximately 52 species of amphisbaenas, of which 18 occur in the northeastern region of the country. Due to the fossorial habits of the amphisbaenas, little is known about the biology of these animals or about their rates of infection by parasites. Of all of the species that occur in northeastern Brazil, only Amphisbaena alba has been examined for macroparasites: nematodes (Aplectana pusilla Miranda, 1924 and A. unguiculate [Rud, 1819]) and pentastomids (Raillietiella giliolii) (Vicente et al., 1993; Almeida et al., 2006). There is only data available concerning microparasites from Valverde et al. (2005), who reported coccidian cysts in A. alba and A. vermicularis.

Raillietiella gigliolii is a species of pentastomid parasite of amphisbaenas that has been described as being specific to A. alba (Rego, 1983; Ali et al., 1984). Hett (1924) described the species based only on male specimens. A description of the females was only later made by Ali et al. (1984) using material from Trinidad (in the Caribbean). A taxonomic review was undertaken by Ali et al. (1985), and in this work (as in all of the earlier publications), $R$. gigliolii was described as a specific parasite of A. alba.

Rego (1983) reported the occurrence of three male specimens of $R$. gigliolii in a specimen of $A$. alba from an undisclosed locality in Brazil. Another occurrence was reported by Almeida et al. (2006) with an analysis of three male specimens collected from the lungs of a specimen of $A$. alba collected in the municipality of Crato, Ceará State, northeastern Brazil. Almeida et al. (2006) published the first data available concerning parasite infection rates (prevalence and infection intensity) even though only three specimens of $A$. alba were available.

The present study was undertaken to investigate infection rates (prevalence and mean infection intensity) for pentastomids in two sympatric and syntopic Amphisbaena species.

\section{Materials and Methods}

The present study with $A$. alba was undertaken from November to December 2007 in an area of remnant Atlantic Forest belonging to the Companhia Usina São João farm, located in the municipality of Cruz do Espírito Santo, Zona da Mata, Paraíba state, Brazil. The forest fragment chosen for the study $\left(07^{\circ} 10^{\prime} \mathrm{S}\right.$ and $\left.35^{\circ} 05^{\prime} \mathrm{W}\right)$ is situated within a sugar cane plantation matrix along its northern border, while it is defined along its southern border by the BR 101 Federal Highway. The forest fragment has an area of 731.5 ha and can be characterised as regenerating secondary forest, with woody species (trees and shrubs) representing many different plant families. Some of the forest areas have an understory layer with herbaceous plants and even grasses (as a result of anthropogenic interference). Epiphytes and vines are present in the area, indicating the recuperation of the forest. The study site is cut (east to west) by the Massangana River, which was dammed to form the Cafundó Reservoir.

Field work to capture Amphisbaena vermicularis was carried out from January to May 2008 on the lower slopes of the Chapada do Araripe Mountains (07 $16^{\prime} \mathrm{S}$ and $39^{\circ} 26^{\prime} \mathrm{W}$ ) within the limits of the Chapada do Araripe Environmental Protection Area in the municipality of Crato, Ceará State, Brazil. The vegetation of the region is composed of secondary forests. The area has been subjected to anthropogenic alterations as a result of occupation for agricultural purposes, harvesting natural resources, and land sub-divisions. The regional climate is warm, semi-arid tropical, with mean annual temperatures between 24 and $26{ }^{\circ} \mathrm{C}$. The rainy season extends from January to May, and the average annual rainfall is 1,100 mm (IPECE, 2008).

The amphisbaenids were captured by using the classical herpetological techniques of active patterned collecting (Auricchio and Salomão, 2002). After collection, the animals were euthanised with ether, fixed, and then preserved in $70 \%$ ethanol. The amphisbaenids were subsequently identified according to Barros-Filho and Valverde (1996) and Vanzolini (2002). Snout-vent length (SVL) was measured using calipers (in centimetres).

The respiratory tracts of the amphisbaenids were removed and the presence of pentastomids determined by examination under a stereomicroscope. All pentastomids found were cleared in Hoyer's medium and subsequently mounted on slides. Identifications were based on the dimensions of the hooks and copulatory spicules of the males that were measured using a microscope fitted with a micrometric ocular (Ali et al., 1984, 1985). Drawings were made using a drawing tube connected to a brightfield microscope. The eco-parasitological terminology used followed Bush et al. (1997).

\section{Results}

A total of 21 amphisbaenids were captured. The nine specimens of A. alba ranged in SVL from 42.0 to $63.0 \mathrm{~cm}($ mean $=51.1 \pm 2.5 \mathrm{~cm})$, while the 12 specimens of A. vermicularis ranged from 20.0 to $50.5 \mathrm{~cm}$ $($ mean $=40.0 \pm 3.0 \mathrm{~cm})$.

Analyses of the specimens of $A$. alba revealed that five individuals were infected by Raillietiella gigliolli (prevalence of $55.5 \%$, mean infection intensity $5.0 \pm 2.53$ with amplitudes of 1-13) (Table 1).

The analyses of A.vermicularis indicated that six individuals were infected by $R$. gigliolli (prevalence of $50 \%$, mean infection intensity $5.3 \pm 2.1$ with amplitudes of 1-14) (Table 1). This represents the first record of R. gigliolii as a parasite of A. vermicularis.

The mean of SVL between infected and non-infected individuals and between males and females did not differ significantly.

\section{Discussion}

As precision in measuring infection rates is intimately related to sample size, significant efforts should be 
Table 1. Pulmonary infection by Raillietiella gigliolii in Amphisbaena species (with their respective host habitat type), and values of prevalence (in \%), intensity of infection, the corresponding range of the intensity of infection, and data source.

\begin{tabular}{|c|c|c|c|c|c|c|}
\hline Host & Biome & $\mathbf{N}$ & SVL $(\mathrm{cm})$ & Prevalence & Infection intensity & Source \\
\hline A. alba 우 & $\begin{array}{l}\text { Atlantic } \\
\text { Forest }\end{array}$ & 8 & $52.24 \pm 2.49$ & $50 \%(4 / 8)$ & $6.0 \pm 3.0(1-13)$ & Present study \\
\hline A. alba $\widehat{\delta}$ & $\begin{array}{l}\text { Atlantic } \\
\text { Forest }\end{array}$ & 1 & 42.0 & $100 \%(1 / 1)$ & $1.0 \pm 0.0$ & Present study \\
\hline A. alba + & Caatinga & 3 & $48.66 \pm 16.75$ & $33.3 \%(1 / 3)$ & $3.0 \pm 0.0$ & Almeida et al. (2006) \\
\hline A. vermicularis $q$ & Caatinga & 10 & $48.80 \pm 2.93$ & $40 \%(4 / 10)$ & $3.5 \pm 1.83(1-9)$ & Present study \\
\hline A. vermicularis $\hat{\sigma}$ & Caatinga & 2 & $42.0 \pm 2.0$ & $100 \%(2 / 2)$ & $2.0 \pm 1.0(1-3)$ & Present study \\
\hline
\end{tabular}

taken to adequately census study populations - although this is not easily done with fossorial animals that are difficult to collect. Almeida et al. (2006) were able to collect only three specimens of $A$. alba and reported an infection rate of $33.3 \%(1 / 3)$ and an infection intensity of $3.0 \pm 0.0$. The results of the present study are quite different, demonstrating significantly higher prevalence and intensity of infection values (Table 1).

Pentastomid host specificity was defended by Self and Kuntz (1967) who pointed out their long evolutionary association; while Riley (1986) estimated that approximately $50 \%$ of the Pentastomid species were specific for their hosts. Our results demonstrate that $R$. gigliolii is not specific to A. alba. Similar results were presented in the study of Almeida et al. (2007, 2008a, 2008b) for various species of snakes and lizards parasitised by Cephalobaena tetrapoda and Raillietiella mottae respectively. The snakes and lizards studied by these authors demonstrated overlapping diets, similar to that seen for A. alba and A. vermicularis in the present work. Almeida et al. (2006) hypothesised that termites and ants must be the intermediate hosts of $R$. gigliolii, and we encountered these arthropods in the stomachs of both amphisbaenids species studied here.

According to Aho (1990), prevalence values above $50 \%$ indicate that the parasite species in question may be the "core" species of the host's helminth community. Only A. alba demonstrated a prevalence level of 55.5\% in the present study, but data obtained by Almeida et al. (2006, 2007, 2008a, 2008b) indicated that pentastomids are not "core" species in lizards and snakes.

Tissue lesions caused by pentastomids are most common in the larva and nymphal stages (due to their migratory process when organs can be perforated) and during encysting (which can cause marked granulomatous inflammations (Ambrose and Riley, 1988; Boyce and Kazacos, 1991). Final hosts, however, do not normally present visible symptoms (pentastomids are rarely coughed up or regurgitated) or tissue damage (such as discoid scars covering the reticular or membranous regions of the lung) (Riley, 1981; Almeida et al., 2008a). Riley (1986: 98), in fact, observed that there is little evidence that pentastomids are responsible for significant pathologies in naturally infected definitive hosts. In the present study, the lung tissue was observed to be intact and without lesions, scars, or traces of hemorrhaging.

As such, additional studies with larger samples will be necessary to elucidate additional details of parasitism in amphisbaenas.

Acknowledgements - We are grateful to the Fundação Cearense de Apoio ao Desenvolvimento Científico e Tecnológico FUNCAP, for our research grant (BPI-0112-2.05/08), the scholarship awarded to S.C. Ribeiro and the productivity fellowship for W.O. Almeida (02/2008-BPI); to the Brazilian National Research Council - CNPq, for its support through a PIBIC scholarship to DL. Sales; the Fundação Coordenação de Aperfeiçoamento de Pessoal de Nível Superior - CAPES for the scholarship awarded to G.G. Santana; the Brazilian Institute for the Environment and Natural Resources - IBAMA for the collecting permit (process number 14100-1 and 007/ 2007 CGFAP/ IBAMA 02007.001009/2004); and Roy Funch (UEFS) for reviewing the manuscript. The experiments described here comply with current Brazilian regulations.

\section{References}

ALI, JH., RILEY, J. and SELF, JT., 1984. A revision of the taxonomy of pentastomid parasites (genus Raillietiella Sambon, 1910) from American snakes and amphisbaenias. Systematic Parasitology, vol. 6, no. 2, p. 87-97.

ALI, JH., RILEY, J. and SELF, JT., 1985. A review of the taxonomy and systematics of the pentastomids genus Raillietiella Sambon, 1910 with a description of a new species. Systematic Parasitology, vol. 7, no. 2, p. 111-123.

ALMEIDA, WO., FERREIRA, FS., BRITO, SV. and CHRISTOFFERSEN, ML., 2006. Raillietiella gigliolii (Pentastomida) infecting Amphisbaena alba (Squamata, Amphisbaenidae): a first record for Northeast Brazil. Revista Brasileira de Biologia = Brazilian Journal of Biology, vol. 66, no. 4, p. 29-41.

ALMEIDA, WO., VASCONCELLOS, A., FREIRE, EMX. and LOPES, SG., 2007. Prevalence and intensity of pentastomid infection in two species of snakes from Northeast Brazil. Revista Brasileira de Biologia = Brazilian Journal of Biology, vol. 67 , no. 1, p. 759-763.

ALMEIDA, WO., COSTA, TBG., FREIRE, EMX. and VASCONCELLOS, A., 2008a. Pentastomid infection in Philodryas nattereri Steindachner, 1870 and Oxybelis aeneus (Wagler, 1824) (Squamata: Colubridae) in a caatinga of 
Northeastern Brazil. Revista Brasileira de Biologia = Brazilian Journal of Biology, vol. 68, no. 1, p. 193-197.

2008b. Pentastomid, Raillietiella mottae Almeida, Freire and Lopes, 2008, infecting lizards in an area of caatinga, northeast, Brazil. Revista Brasileira de Biologia = Brazilian Journal of Biology, vol. 68, no. 2, p. 203-207.

AMBROSE, NC. and RILEY, J., 1988. Light microscope observations of granulomatous reactions against developing Porocephalus crotali (Pentastomida: Porocephalida) in mouse and rat. Parasitology, vol. 97, no. 1, p. 27-42.

AURICCHIO, P. and SALOMÃO, MG., 2002. Técnicas de coleta e preparação de vertebrados para fins científicos $e$ didáticos. São Paulo: Instituto Pau Brasil de História Natural. $348 \mathrm{p}$.

BARROS-FILHO, JD. and VALVERDE, MCC., 1996. Notas sobre os Amphisbaenia (Reptilia, Squamata) da Microrregião de Feira de Santana, Estado da Bahia, Brasil. Sitientibus, vol. 14, no. 14 , p. $57-68$.

BOYCE, WM. and KAZACOS, EA., 1991. Histopathology of nymphal pentastomid nfections (Sebekia mississippiensis) in paratenic hosts. The Journal of Parasitology, vol. 77, no. 1, p. $104-110$.

BUSH, AO., LAFFERTY, KD., LOTZ, JM. and SHOSTAK, AW., 1997. Parasitology meets ecology in its own terms: Margulis et al. revisited. The Journal of Parasitology, vol. 83, no. 4 , p. $575-583$.

HETT, ML., 1924. On the family Linguatulidae. Proceedings of the Zoological Society of London, vol. 1, p. 107-159.
Instituto de Pesquisa e Estatística Econômica do Ceará - IPECE, 2008. Perfil básico municipal: Crato. Ceará: Secretaria do Planejamento e Coordenação. Available from:<http://www. iplance.ce.gov.br/publicacoes/perfil_basico/PBM_2008/Crato. pdf>.

REGO, AA., 1983. Pentastomídeos de répteis do Brasil: Revisão dos Cephalobaenidae. Memórias do Instituto Oswaldo Cruz, vol. 78 , no. 4, p. 399-411.

RILEY, J., 1981. An experimental investigation of the development of Porocephalus crotali (Pentastomida: Porocephalida) in the western diamond back rattlesnake (Crotalus atrox). International Journal for Parasitology, vol. 11, no. 2, p. 127-131.

1986. The biology of pentastomids. Advances in Parasitology, vol. 25, p. 45-128.

SELF, JT. and KUNTZ, RE., 1967. Host-parasite relations in some Pentastomida. The Journal of Parasitology, vol. 53, no. 1, p. 202-206

VALVERDE, MCC., PACHECO, DC. and LEITE, FHA., 2005. Ocorrência de cistos parasitários no rim de duas espécies de Amphisbaena (Reptilia: Squamata). Sitientibus, vol. 5, no. 1, p. 9-11.

VANZOLINI, PE., 2002. An aid to the identification of the South American species of Amphisbaena (Squamata, Amphisbaenidae). Papéis Avulsos de Zoologia, vol. 42, no. 15, p. $351-362$

VICENTE, JJ., RODRIGUES, HO., GOMES, DC. and PINTO, RM., 1993. Nematóides do Brasil. Terceira parte: nematóides de répteis. Revista Brasileira de Biologia $=$ Brazilian Journal of Biology, vol. 10, no. 1, p. 19-168. 